\title{
Muslim Paruh Waktu di SMAN 6 dan SMKN 2 Kota Padang
}

\author{
Andri Ashadi \\ UIN Imam Bonjol Padang \\ andri.ashadi.4@gmail.com
}

\begin{abstract}
Some Islamic programs both in SMAN 6 nor in SMKN 2 such as Muslim-Muslim clothing, learning of Islamic Religion and Character Education are not only aimed to Muslim students, but also involve non-Muslim (Christian) students. In this position Christian students are faced with a conflict of identity. On the one hand, they are not possible to establish Islamic identity as Muslim students because the religion is a dogma that does not cast doubt. On the other hand, they were almost impossible to get out of various Islamic programs because it was a regional policy and in the public schools was embodied in several of rules and rule of schools. This paper presents a study of how they imitate the Islamic identity of the school's public space and how they interpret the imitation process. Based on the results of observations, interviews, and FGDs with schools, Christian students, their parents, Padang City Christian religious leaders and Padang City Education Office, this paper concludes that Christian students try to imitate "like" Muslim students. It's just they behave "like" Muslim students are more meaningful than self-adjustment which has nothing to do with religion. While religion is interpreted as faith and belief and that is the real of religion. [Beberapa program keislaman baik di SMAN 6 maupun di SMKN 2 seperti kewajiban berbusana muslim-muslimah,
\end{abstract}


kultum dan pembelajaran Pendidikan Agama Islam dan Budi Pekerti tidak hanya ditujukan terhadap siswa muslim, namun juga melibatkan siswa non-muslim (Kristen). Dalam posisi tersebut siswa Kristen dihadapkan pada benturan identitas. Di satu sisi, mereka tidak mungkin untuk menjati-dirikan identitas keislaman sebagaimana layaknya siswa muslim lantaran agama adalah dogma yang tidak meruangkan keraguraguan. Mereka hampir tidak mungkin pula keluar dari berbagai program keislaman lantaran hal tersebut merupakan kebijakan daerah dan di sekolah-sekolah umum negeri dijelmakan dalam berbagai aturan dan tata tertib sekolah. Paper ini menghadirkan kajian tentang bagaimana mereka meniru identitas keislaman ruang publik sekolah dan bagaimana pula mereka memaknai proses peniruan tersebut. Berdasarkan hasil-hasil observasi, wawancara, dan FGD dengan pihak sekolah, siswa Kristen, para orang tua mereka, pemuka agama Kristen Kota Padang dan Dinas Pendidikan Kota Padang, paper ini menyimpulkan bahwa bahwa siswa Kristen berusaha meniru untuk "seperti" siswa muslim. Hanya saja berperilaku "seperti" siswa muslim lebih mereka maknai sebatas penyesuaian diri yang tidak ada hubungannya dengan agama. Sementara agama dimaknai sebagai iman dan keyakinan dan itulah agama yang sesungguhnya.]

Keywords: Christian students, school public spaces and imitation

\section{Pendahuluan}

"Anda non-muslim?”, "Muslim pak!" Jawab dua orang siswi yang melintas di depannya. "Bukan, muslim pak!" jawab yang lain ketika kepala sekolah menggulang pertanyaan yang sama. "Itu?" sambil menunjuk belasan siswa yang berdiri beberapa langkah di depannya, serentak mereka menjawab, "muslim semua pak!". ${ }^{1}$ Di lain waktu, wakil kesiswaan sebuah sekolah negeri mengaku sering salah ketika memanggil siswanya untuk menunaikan salat berjamaah. "Salat, salat!", "kenapa kamu tidak salat?"

\footnotetext{
${ }^{1}$ Hasil Observasi di SMAN 6 Padang, 13-09-2014.
} 
"Saya non Pak" (maksudnya non muslim), kiranya bukan muslim," ungkapnya sambil terheran. ${ }^{2}$

Kutipan pertama terjadi saat peneliti meminta kesediaan kepala sekolah sebuah SMA Negeri di Kota Padang menghadirkan beberapa siswa non-muslim untuk keperluan wawancara, lalu terjadilah dialog seperti di atas. Kepala sekolah tampak kesulitan mengidentifikasi identitas keagamaan siswanya ketika sekolah yang dipimpimnya menjadi seragam dan tertutup. Ia bahkan sampai berulang-ulang menanyakan "anda nonmuslim" untuk sekedar membedakan mana yang muslim dan non-muslim. Sedangkan kutipan kedua menggambarkan bagaimana pengalaman wakil kesiswaan sebuah SMK Negeri di Kota ini ketika melakukan pembinaan keagamaan (keislaman) yang sebenarnya hanya ditujukan untuk siswa muslim, namun tanpa disadari telah berimplikasi terhadap siswa nonmuslim (baca Kristen). Ini menunjukkan bahwa pada satu sisi telah terjadi pergeseran ruang publik sekolah dari bersifat umum-kewargaan menjadi ruang publik muslim. Di saat yang sama juga membuktikan bahwa kebijakan penyeragaman telah berimplikasi terhadap keberadaan siswa Kristen pada kedua sekolah yang mau tidak mau terpaksa mengindentikkan diri dengan struktur kemusliman ruang publik sekolah.

Dalam kondisi seperti itu, siswa Kristen dihadapkan pada benturan identitas. Di satu sisi, mereka tidak mungkin untuk menjati-dirikan identitas keislaman sebagaimana layaknya siswa muslim lantaran agama dalam konteks kekristenan adalah dogma iman yang tidak menyediakan ruang bagi keragu-raguan. ${ }^{3}$ Pada bagian lain, seorang siswa Kristen yang berstatus sebagai siswa sekolah umum negeri di lingkungan Pemerintah Kota Padang hampir tidak mungkin keluar dari berbagai program dan kegiatan keislaman lantaran hal tersebut merupakan kebijakan daerah dan di sekolah-sekolah umum negeri dijelmakan dalam berbagai aturan dan tata tertib sekolah.

\footnotetext{
2 SA (58 tahun), Wawancara, 13-9-2014.

${ }^{3}$ Joachim Wach, Ilmu Perbandingan Agama Inti dan Bentuk Pengalaman Keagamaan terj. Djamannuri (Jakarta: PT Rajawali, 1984), 108-109.
} 
Berbagai kebijakan seperti Perda nomor 6 tahun 2003, ${ }^{4}$ Instruksi Walikota nomor 451.422/Binsos-III $/ 2005^{5}$ dan Perda nomor 5 tahun 2011, 6 praktis telah membuat ruang publik sekolah di Kota Padang mengalami intensifikasi kegiatan keislaman. Sejatinya, semua kegiatan di atas hanya ditujukan untuk siswa-siswi muslim. Untuk kewajiban berbusana muslim-muslimah misalnya, memang siswa-siswi non-muslim (termasuk Kristen) sudah tereksklusi karena sesuai dengan instruksi Wali Kota Padang di atas hanya "dianjurkan" untuk memakai baju kurung bagi perempuan dan celana panjang bagi laki-laki (poin kesepuluh pada instruksi tersebut). Namun dalam prakteknya, anjuran itu telah berubah menjadi tidak hanya sekedar berbaju kurung sebagai salah satu identitas budaya Minang, bahkan kewajiban untuk berbusana muslim/muslimah. Ia berubah menjadi kewajiban ketika dijelmakan menjadi aturan dan tata tertib sekolah, ${ }^{7}$ sehingga tidak ada pilihan jika ingin bersekolah pada sekolah-sekolah negeri di Kota Padang tereksklusi dari aturan tersebut. Lebih dari itu, dalam perkembangannya seperti yang dialami siswa/siswi Kristen SMKN 2 dan SMAN 6 Kota Padang mereka juga dituntut untuk "terlibat" dan menjalankan kewajiban keagamaan (baca keislaman) lain. Setiap waktu mereka harus mendengar do'a dan lafaz Alquran dilantunkan menjelang jam pelajaran dimulai, mengikuti kultum termasuk mendengar

\footnotetext{
${ }^{4}$ Perda ini berkaitan kewajiban Pandai Baca Tulis Al quran bagi Peserta Didik Sekolah Dasar dan Madrasah Ibtidaiyah.

${ }^{5}$ Instruksi Walikota itu berisi 12 poin; tentang Pelaksanaan Wirid Remaja, Didikan Subuh dan Anti Togel/Narkoba serta Berpakaian Muslim-Muslimah bagi Murid/Siswa SD/MI,SLTP/MTS dan SLTA/SMK/MA se-Kota Padang tanggal 07 Maret 2005. Instruksi ini ditindaklanjuti oleh surat edaran Kepala Dinas Pendidikan Kota Padang nomor 1565/420.DP/TU.2/2005 terhadap seluruh kepala sekolah SMP, SMA, SMK negeri/swasta dan Kacabdin Pendidikan beserta SD dalam jajarannya untuk melaksanakan instruksi tersebut.

${ }^{6}$ Mempertegas dan melengkapi instruksi Walikota Padang di atas, pada pasal 19 tentang kewajiban peserta didik dalam poin (g) disebut bahwa setiap peserta didik berkewajiban mengikuti dan ikut menyelenggarakan peringatan hari-hari besar keagamaan masingmasing; juga seperti pada poin j dinyatakan pula kewajiban untuk mengikuti pesantren Ramadhan, Wirid remaja, didikan subuh, memakai seragam muslim-muslimah, pandai baca tulis Al quran, menghafal Juz 'Amma dan Asmaul Husna bagi yang beragama Islam. 7 Lihat Lembaran Buku Induk Siswa SMKN 2 Padang atas nama Nurzaman tahun $2013 / 2014$.
} 
senandung asma al-husna dilantunkan, ikut belajar Pendidikan Agama Islam meski mereka diizinkan untuk keluar ruangan bahkan pulang lebih awal. ${ }^{8}$ Singkatnya menggunakan ungkapan sang pencetus kebijakan ini, Fauzi Bahar, "Kalau ada sekawanan domba berwarna putih disela oleh beberapa domba berwarna biru, tentu yang biru harus menyesuaikan diri.", Sementara kegiatan keagamaan mereka sendiri tereksklusi dari ruang publik sekolah.

Pada kedua lokasi tersebut, di samping sedang intensif menjalankan berbagai program keislaman, juga terdapat cukup banyak siswa Kristen yang terdampak langsung oleh berbagai program dimaksud. ${ }^{10}$ Data dihimpun dari sejumlah siswa Kristen SMAN 6 dan SMKN 2, orang tua mereka, pemuka Kristen Kota Padang, pihak sekolah dan Dinas Pendidikan Kota Padang melalui wawancara dan FGD. Selain itu, dilengkapi juga dengan observasi terbatas pada beberapa kegiatan keislaman di atas dan penelusuran terhadap dokumen tertulis berupa tata tertib siswa pada kedua sekolah.

Harus diakui bahwa studi tentang relasi mayoritas-minoritas dalam ruang publik sudah banyak dilakukan. Dalam skala global menurut penelusuran Muhammad Ansor, hal tersebut terjadi di Perancis, Turki, dan Hongkong. ${ }^{11}$ Hanya saja riset-riset tersebut lebih menyorot posisi dan pola-pola negosiasi minoritas muslim terutama perempuan. Di Perancis, perempuan muslim yang meyakini jilbab sebagai kewajiban agama dituntut

\footnotetext{
${ }^{8}$ Sherly, siswa Kristen SMKN 02 Padang, Wawancara, 1804 2014, Nadila, siswa muslim SMKN 2, Wawancara, 19-04-2014.

${ }^{9}$ Meilanie Buitenzorgy, "Jilbab dan Tirani Mayoritas," Http:// hukum. kompasiana com / 2014/ 01/ 30/ jilbab -dan -tirani -mayoritas -631665. html, (diakses 26 Februari 2014). ${ }_{10}$ Pada tahun ajaran 2014/2015 tercatat tidak kurang dari 829 orang siswa menimba ilmu pengetahuan di SMA Negeri 6 Padang yang terdiri dari 809 orang siswa Muslim dan 20 orang siswa Kristen; 12 orang Protestan dan 8 orang Katolik. Sementara dari 1182 orang siswa SMKN 2 yang terdata pada Bulan Juli 2014 terdapat 21 orang pada kelas XI dan XII dan diperkirakan (karena belum didata) sekitar 5 orang di kelas X. Jadi keseluruhan berjumlah 26 orang (Rekap jumlah Siswa Keadaan Bulan Juli 2014 SMKN 2 Padang).

11 Muhammad Ansor, "Salib Dibalik Jilbab: Negosiasi Identitas Perempuan Kristen Berjilbab di Langsa Aceh," Makalab dipresentasikan pada AICIS IAIN Samarinda, 21-24 November 2014, 4.
} 
untuk menyesuaikan diri dengan kebijakan negara yang melarang penggunaan symbol agama di ruang publik. Sejak Revolusi Perancis, di mana gereja dipandang sebagai sumber kebijakan negara yang menindas, pemerintah secara historis mempersempit ruang gerak agama dalam ranah publik. ${ }^{12}$ Di Turki, perempuan muslim berjilbab berhadapan dengan rezim muslim sekuler yang juga melarang penggunaan jilbab di ruang publik. Buku Fatma Nefra Sagi dalam bukunya Religion and the State in Turkis Universities membahas pengalaman pendidikan dan budaya "buka selubung paruh waktu" selama proses belajar mengajar di lembaga-lembaga publik di Turki. Istilah "buka selubung paruh waktu" merujuk kepada mahasiswa yang menutupi rambut mereka dalam kehidupan pribadi mereka, tapi siap untuk menghapus jilbab sementara waktu ketika berada di universitas Turki sebagai akibat dari tinggi kebijakan larangan untuk berjilbab. ${ }^{13}$ Sementara di Hongkong, perempuan muslim Pakistan mengalami alienasi budaya karena pakaian adat yang mereka kenakan. York Y.N. Chow, Ketua Komisi Persamaan dan Kesempatan Hongkong (EOC) pada tahun 2012, menerbitkan laporan mengenai diskriminasi ras yang dialami oleh orang-orang Asia Selatan. EOC menemukan bahwa mencari pekerjaan adalah area utama di mana orang Asia Selatan menghadapi diskriminasi dan prasangka, misalnya dengan adanya persyaratan kemampuan tulis bahasa Cina meski untuk pekerjaan manual. ${ }^{14}$

Untuk konteks nasional, tema ini merupakan fenomena yang relatif baru setidaknya selama dua dasa warsa terakhir. Kajian yang ada lebih banyak berfokus pada penguasaan (hegemoni) ruang publik sekolah dengan nilai-nilai keislaman baik yang diinisiasi oleh negara dalam hal ini pemerintah daerah, para guru agama maupun Rohis (rohaniawan Islam). ${ }^{15}$

12 John R. Bowen, Why the French Don't Like Headscarves: Islam, the State and Public Space (Princeton and Oxford: Princeton University Press, 2007), 65-97.

${ }^{13}$ Fatma Nevra Seggie, "Religion and the State in Turkish Universities The Headscarf Ban,” https://link.springer.com/content /pdf/bfm\%3 A978-0-230-11764-8\% 2F1.pdf (diakses 15 Mei 2015).

14 Http://www.eocdlr.org.hk/downloads/document_indonesian.pdf. (diakses 11 Mei 2015).

${ }^{15}$ Lihat Ismatu Ropi, "Rohis: dari Pencarian Identitas ke Ideologisasi Agama," Dialog Jurnal Penelitian dan Kajian Keagamaan, Vol. 72, No. 2, XXXIV, Nopember 2011: 117-118, 
Tetapi cukup mengejutkan, bahwa studi hegemoni ruang publik sekolah ini jarang dibahas dalam konteks peniruan identitas keislaman dan bagaimana siswa-siswi Kristen memaknai proses tersebut. Makalah ini hendak mendalami bagaimana mereka melakukan proses peniruan identitas keislaman pada kedua sekolah, lalu bagaimana pula mereka mendefinisikan identitas kekristenan sebagai jati diri di satu sisi dengan identitas keislaman sebagai produk peniruan pada sisi lain.

Zainal Abidin Bagir dkk, Pluralisme Kewargaan Arah Baru Politik Keragaman di Indonesia (Yogyakarta: CRCS UGM Bekerjasama dengan Mizan, 2011), 105-107, Hairus Salim HS dkk, Politik. Ruang Publik sekolah Negosiasi dan Resistensi di SMUN di Yogyakarta (Yogyakarta: CRCS-UGM, 2011), 81, Muhammad Ansor, Yang Bersalib Yang Berjilbab: Politik Representasi dan Negosiasi Identitas Perempuan Kristen Langsa (Jakarta: Pusat Penelitian Kehidupan Keagamaan Kementerian Agama Republik Indonesia Tahun, 2013), 26. Mohamad Guntur Romli, "Siswi-Siswi Kristen Pun Terpaksa Berjilbab: Kewajiban Busana Muslim + komentar-komentar,” (diakses 29 Juli 2015).

Http://www.elsam.or.id/downloads/Tulisan_Monitoring_Perda-surur.pdf (diakses 13 April 2014). Andri Ashadi dkk, Pengalaman Multikulturalisme Di Kalangan Pelajar Islam dan Kristen SMA Don Bosco Padang (Padang: Puslit IAIN Imam Bonjol Padang 2013). 


\section{Menjadi Ruang Publik Muslim}

SMAN $6^{16}$ dan SMKN $2^{17}$ merupakan satuan pendidikan menengah sebagai lanjutan dari pendidikan dasar. Hanya saja sebagai lembaga pendidikan umum, SMA lebih mengutamakan perluasan pengetahuan yang diperlukan peserta didik untuk melanjutkan pendidikan ke jenjang yang lebih tinggi. ${ }^{18}$ Sementara SMK disebut sebagai pendidikan kejuruan yang mempersiapkan peserta didik terutama untuk bekerja pada bidang tertentu. ${ }^{19}$ Ini setidaknya sudah menegaskan bahwa SMA dan SMK berbeda dari lembaga pendidikan yang lain seperti lembaga pendidikan keagamaan; madrasah atau pondok pesantren yang berfungsi untuk mempersiapkan peserta didik menjadi anggota masyarakat yang memahami dan mengamalkan nilai-nilai ajaran agamanya dan atau menjadi ahli ilmu agama. ${ }^{20}$ Namun dalam satu dasawarsa terakhir kedua sekolah telah berubah dari lembaga pendidikan umum dan kejuruan ke institusi

\footnotetext{
16 SMA Negeri 6 didirikan pada 14 Januari tahun 1984, merupakan kelas jauh dari SMA Negeri 1 Padang. Memiliki gedung sendiri dengan lahan seluas $15.000 \mathrm{M}^{2}$ dan yang terpakai untuk bangunan seluas $9.300 \mathrm{M}^{2}$. Pada tahun ajaran 2014/2015 tercatat tidak kurang dari 829 orang pelajar menimba ilmu pengetahuan di SMA Negeri 6 Padang yang terdiri dari 809 orang pelajar Muslim dan 20 orang pelajar Kristen; 12 orang Protestan dan 8 orang Katolik. Tidak terdapat pelajar dari agama lain seperti Hindu, Budha dan Konghucu. Lihat Sejarah Singkat SMA Negeri 6 Padang, Mei 2014.

${ }^{17}$ SMKN 2 didirikan pada Juli 1951 untuk mengatasi kesulitan angakatan muda Sumatera Barat masuk ke sekolah-sekolah ekonomi. Di samping itu, juga didasarkan atas kenyataan bahwa masyarakat Minang sebagian besar mengandalkan hidup dari perdagangan.

(http/invest.smk2padang.sch.id/html/index.php?id=profil\&kode $=11 \&$ profil $=$ Visi $\% 20$ dan\%20Misi (25 September 2014). Total siswa sebanyak 1182 orang dengan rincian 1156 orang pelajar Muslim, selebihnya 21 orang pada kelas XI dan XII adalah pelajar Kristen serta diperkirakan sekitar 5 orang di kelas X. Jadi keseluruhan berjumlah 26 orang (Rekap jumlah Siswa Keadaan Bulan Juli 2014 SMKN 2 Padang). (SA (58 tahun), Wawancara, 1510-2014).

${ }^{18}$ Lihat Salinan Peraturan Menteri Pendidikan dan Kebudayaan nomor 69 tahun 2013 tentang Kerangka Dasar dan Struktur Kurikulum untuk Sekolah Menengah Atas/Madrasah Aiyah, 10.

19 Peraturan Menteri Pendidikan dan Kebudayaan Indonesia nomor 70 tahun 2013 tentang Kerangka Dasar dan Struktur Kurikulum Sekolah Menengah Kejuruan/Madrasah Aliyah Kejuruan, 8, lihat juga Salinan Peraturan Menteri Pendidikan dan Kebudayaan Republik Indonesia Nomor 64 Tahun 2013 tentang Standar Isi Pendidikan Dasar dan Menengah, 8.

${ }^{20}$ Ibid., 9.
} 
pendidikan yang bernuansa religius layaknya madrasah atau pondok pesantren. Lugasnya dari ruang publik umum menuju ruang publik muslim.

Di SMAN 6 perubahan ini setidaknya terlihat pada visi sekolah; berakhlak mulia, berprestasi, kompetitif dan berbudaya lingkungan. Visi berakhlak mulia segera bersambut dengan misi pertamanya membentuk peserta didik yang berakhlak mulia. Untuk itu dalam prakteknya seperti yang dijelaskan sebelumnya berbagai kegiatan keislaman intensif dilakukan pada hari-hari dan jam belajar, termasuk kegiatan mingguan berupa wirid remaja dan kegiatan tahunan seperti pesantren Ramadhan.

Visi berakhlak mulia memang sengaja dikedepankan bahkan dipertajam agar sejalan dengan prinsip program pemerintah Kota Padang yaitu terwujudnya warga kota yang berbudaya tinggi dengan adat dan kebudayaan Minangkabau sebagai nilai dasar utama dengan keimanan dan ketaqwaan yang berkualitas serta penguasaan ilmu pengetahuan dan teknologi yang tinggi. Untuk itu salah satu misi yang dicanangkan Pemerintah Kota Padang adalah meningkatkan dan menjunjung tinggi nilai-nilai agama, adat, seni dan budaya. ${ }^{21}$ Hanya saja pihak sekolah keberatan kalau visi tersebut semata karena menyesuaikan dengan visi dan misi Pemerintah Kota Padang. Jauh sebelumnya visi berakhlak mulia sudah dirumuskan, persisnya sejak 12 tahun yang lalu. ${ }^{22}$ Namun jika dikaitkan dengan rezim yang berkuasa saat itu, Walikota Fauzi Bahar, tampaknya visi dimaksud tetap saja sejalan dengan untuk tidak menyebut menyesuaikan dengan visi rezim yang berkuasa. Bahkan di masa Fauzi Bahar berbagai kebijakan religius itu digulirkan seperti instruksi pakaian muslim-muslimah, sertifikat lulus membaca Alquran sebagai persyaratan untuk masuk ke jenjang pendidikan selanjutnya, pesantren Ramadhan, wirid remaja dan perlombaan membaca dan menghafal asma al-busna antar sekolah yang disediakan langsung hadiahnya oleh pemerintah kota Padang saat itu. Saking banyaknya kebijakan yang bernuansa keagamaan, ada

\footnotetext{
${ }^{21} \mathrm{http}: / /$ www.padang.go.id/index.php?option $=$ com_content\&view $=$ article\&id $=48 \&$ Ite mid=54 (diakses 15 Oktober 2014).

${ }^{22}$ R (47 tahun), Kepala Sekolah SMAN 6, Wawancara, 13-09-2014.
} 
pengamat yang menyebut Kota Padang telah berubah menjadi kota hijau alias kota santri. ${ }^{23}$

Selain itu, juga karena tuntutan kurikulum 2013. Di dalam kurikulum tersebut terdapat kompetensi inti-1 (KI-1) yaitu kompetensi inti sikap spiritual, di samping kompetensi Inti-2 (KI-2) untuk kompetensi inti sikap sosial, kompetensi inti-3 (KI-3) kompetensi inti pengetahuan dan kompetensi inti-4 (KI-4) kompetensi inti keterampilan. Untuk kelas X. XI dan XII kompetensi inti sikap spritualnya adalah menghayati dan mengamalkan ajaran agama yang dianutnya. ${ }^{24}$ Untuk yang beragama Islam, sikap spiritual ini menurut salah seorang guru Agama Islam SMA Negeri 6, diambilkan dari nilai ibadah; dari salat Dhuhur dan salat Jumat. Sebelum salat berjamaah diadakan kultum atau ceramah singkat. ${ }^{25}$ Sementara pada setiap Jumat pagi diadakan muhadharah satu paket dengan pembacaan ayat suci Alquran, saritilawah dan nyanyian religi. Kalau yang dua ini tidak dilaksanakan, maka KI-1nya dianggap tidak tuntas. ${ }^{26}$ Kendati dalam prakteknya diakui bahwa hal tersebut memang membutuhkan kesadaran dan pembiasaan dalam lingkungan keluarga. Kalau nilai-nilai agama terinternalisasi dengan baik dalam keluarga, maka tidak terlalu sulit untuk melakukan pembiasaan serupa dalam lingkungan sekolah. Sebaliknya, diakui juga, tidak jarang berbagai progam keislaman berjalan "seadanya" di tangan siswa-siswi yang setelah ditelusuri mengalami masalah pembinaan agama dalam lingkungan keluarga.

Hal serupa juga terjadi di SMK Negeri 2. Uniknya, meski tidak mencanangkan visi berakhlak mulia seperti SMA negeri 6 di atas dan dalam ritme kegiatan pembelajaran yang cukup padat, kegiatan-kegiatan lain termasuk kegiatan keagamaan juga sarat direncanakan. Selain yang sudah

\footnotetext{
${ }^{23}$ Ashadi, Andri dkk, Pengalaman Multikulturalisme di Kalangan Pelajar Islam dan Kristen SMA Don Bosco Padang (Padang: Pusat Penelitian dan Penerbitan IAIN Imam Bonjol Padang, 2013), 14-15.

${ }^{24}$ Lihat Salinan lampiran Peraturan Menteri Pendidikan dan Kebudayaan Nomor 69 tahun 2013 tentang Kerangka Dasar dan Struktur Kurikulum Sekolah Menengah Atas/Madrasah Aliyah, 6-7.

${ }^{25}$ A (42 tahun), Guru Agama Islam SMAN 6, Wawancara, 18-09-2014.

${ }^{26}$ A (42 tahun), Guru Agama Islam SMAN 6, Wawancara, 18-09-2014.
} 
lazin dilaksanakan seperti belajar agama Islam, berdoa dan mengaji sebelum belajar, salat berjamaah, kultum, pelaksanaan hari-hari besar keagamaan, untuk tahun 2014/2015 juga direncanakan pelaksanaan lomba baca Alquran tingkat SD/SLTP/SLTA se-Kota Padang, mengikuti lombalomba kegiatan keagamaan, mengikuti undangan kegiatan keagamaan dan seminar tentang kehidupan remaja Islam madani. ${ }^{27}$ Di samping itu mereka juga harus memilih salah satu dari jenis kegiatan ekstra kurikuler yang disediakan misalnya agama atau kerohanian yang dilaksanakan pada setiap hari Sabtu.

Pertanyaannya adalah apa yang melatar belakangi kegiatan-kegiatan tersebut? Pertama, sekolah ini sedang bermetamorfosis dari sebelumnya berstandar internasional kategori SBI Invest tahun $2013^{28}$ menjadi SMK model yang mengembangkan fungsi tunggal yaitu menyiapkan peserta didik untuk memasuki lapangan kerja pada bidang tertentu menjadi SMK yang mengembangkan multi-fungsi (fungsi majemuk) selaras dengan kebutuhan peserta didik dan kemajemukan kebutuhan masyarakat serta dunia kerja dalam berbagai sektor, dan sub-sub sektornya, baik primer, sekunder, tersier maupun kuarter. Oleh sebab itu, SMK model dituntut untuk menjadi sekolah cerdas dan kreatif dalam mengembangkan program-programnya, memiliki keunggulan-keunggulan dibandingkan dengan SMK-SMK lain dalam inputnya (kurikulum, guru, fasilitas, dan sebagainya), prosesnya (pembelajaran, menajemen, kepemimpinan, dan sebagainya), dan outputnya (mutu lulusan dan mutu produk-produk lain yang dihasilkan). ${ }^{29}$

Dari kerangka di atas khusus untuk keunggulan mutu lulusan, maka dikembangkan berbagai program seperti program Kebangsaan/Nasionalisme/Patriotisme: (1) pelaksanaan upacara bendera,

${ }^{27}$ Lihat Matrix Kegiatan dan Usulan Angaran Tahun Pelajaran 2014/2015 oleh SA (58 tahun), pihak SMK Negeri 2 Padang, 2.

${ }^{28}$ SA (58 tahun), pihak SMKN 2, Program Kerja, Matrix Kegiatan dan Usulan Anggaran Tabun 2014/2015, 1.

29 Slamet PH, "Pengembangan SMK Model untuk Masa depan," http: //download.portalgaruda.org/ article.php? article=102529\&val=445 (diakses 15 Oktober 2014). 
(2) pelaksanaan upacara bendera OSIS, (3) patroli keamanan sekolah, (4) Palang Merah Remaja (PMR) dan UKS, (5) pembinaan kelompok Sispala, (6) pembinaan karakter kewiraan dan cinta tanah air, (7) pelaksanaan lomba PBB dan gerak jalan antar kelas/sekolah, (8) persiapan menyambut hari besar nasional, (9) pembinaan kepramukaan, (10) pembinaan latihan PBB, (11) pembinaan tertib di jalan raya (lalu lintas), dan 12 pembinaan anti narkoba, ${ }^{30}$ termasuk kegiatan-kegiatan keislaman di atas.

Kedua, dalam rangka peningkatan akhlak dan kesadaran beragama anak-anak. Anak-anak ini ungkap Wakil Kesiswaan SMKN 2, dalam usia remaja, dalam masa pencarian jati diri. Jadi perlu pembinaan-pembinaan. Argumen ini cukup beralasan terlebih pada tahun yang sama terungkap semakin meningkatnya kenakalan siswa dan penyakit masyarakat (pekat) di Kota Padang. Jika di tahun sebelumnya (2013) terdapat 1.420 kasus, maka pada tahun 2014 naik menjadi 2.116 kasus. Dari 2.116 kasus, 615 kasus di antaranya adalah kasus kenakalan siswa, disusul 613 kasus pekat, 498 kasus penertiban PKL (pedagang kaki lima) dan 114 kasus pengamen jalanan. Menurut A, Kasi Trantib pol PP Padang, kasus kenakalan siswa di kota ini memang tidak pernah sepi. Hampir setiap hari ada siswa yang ditangkap, mulai dari bolos sekolah, judi, miras hingga tawuran. ${ }^{31}$ Dalam kondisi seperti ini tidak mudah melakukan pembinaan keagamaan. Mulamula yang termotivasi melakukan salat berjamaah misalnya tidak banyak, tapi dengan selalu diajak, dimotivasi dan disosialisasikan akhirnya bertambah banyak juga. ${ }^{32}$ Hanya saja Wakil Kurikulum SMKN 2 tetap saja mengeluhkan perilaku siswanya yang berbeda sekali antara di sekolah dan di luar sekolah. Apakah agama ini sudah membosankan mereka, tanyanya? Pertanyaan yang kemudian ia jawab sendiri bahwa orang menjadi baik itu didukung oleh tiga hal; lingkungan sekolah, keluarga dan masyarakat.

Contoh lain yang diberikan adalah dalam soal berpakaian. Ketika pergi jalan-jalan mereka tetap mengenakan busana muslim-muslimah akan

\footnotetext{
30 Lihat kembali Matrix Kegiatan-kegiatan "Karakter Kebangsaan/Nasionalisme/Patriotisme," pihak SMKN 2 tahun 2014/2015. ${ }^{31} \mathrm{Http}: / /$ www.koran.padek.co/read/detail/14973(diakses 21 Maret 2015). ${ }^{32} \mathrm{SA}$ (58 tahun), pihak SMKN 2, Wawancara, 11-09-2014.
} 
tetapi dengan model celananya ketat dan pakai baju kaus. Ini juga tampak saat peneliti menawarkan untuk mewawancarai para orang tua siswa perempuan, umumnya mereka keberatan yang menyiratkan terdapat masalah antara pembinaan keagamaan di sekolah dengan perilaku seharihari mereka di rumah atau di luar sekolah. Pernah juga menurut pengakuan Y, salah seorang guru Pendidikan Agama Islam pada sekolah tersebut, ada orang tua yang protes ke sekolah. Ia keberatan kalau anaknya diberi nilai 80 untuk mata pelajaran Pendidikan Agama Islam. Seharusnya tidak usah diluluskan karena terlalu jauh jarak antara nilai agama yang ia dapatkan di sekolah dengan perilaku beragamanya. ${ }^{33}$

\section{Tak Ada Pilihan Selain Meniru}

Secara umum, semua program dan kegiatan keislaman pada kedua sekolah hanya ditujukan untuk siswa-siswi muslim. Beberapa ketentuan dalam tata tertib sekolah secara tegas menyebutkan bahwa "Setiap siswa dan siswi yang muslim dam muslimah wajib salat berjamaah di mushola pada saat Dhuhur dan Ashar." 34 Juga disebutkan bahwa, "Siswa muslim wajib membawa kelengkapan salat dan Al quran setiap hari." ${ }^{35}$ Kedua ketentuan ini sudah mengeklusi siswa non-muslim termasuk siswa Kristen dari kewajiban tersebut. Jika menggunakan logika oposisi binner dapat dikatakan bahwa selain siswa muslim tidak diwajibkan untuk melaksanakan salat berjamaah termasuk membawa perlengkapan salat dan Alquran setiap hari. Lalu bagaimana dengan peraturan lain yang tidak secara tegas memuat ketentuan serupa misalnya ketentuan tentang berpakaian. Dalam tata tertib khusus poin kewajiban siswa disebutkan, "Hari Senin s/d Rabu dan Sabtu siswa memakai celana/rok abu-abu dan baju putih (baju kurung bagi yang perempuan sesuai model yang ditetapkan dengan mudhawarahnya/segi tiga, tutup kepala tanpa rendo atau polos...." ${ }^{36}$ Di samping itu disebutkan pula, "Pada hari Jumat siswa puteri

\footnotetext{
33 Y (54 tahun), Guru Pendidikan Agama Islam SMKN 2, Wawancara, 17-09-2014. ${ }^{34}$ Y (54 tahun), Guru Pendidikan Agama Islam SMKN 2, Wawancara, 17-09-2014. ${ }^{35}$ Lihat misalnya Peraturan dan Tata Tertib Siswa SMKN 2 Padang Tahun 2013 yang masih tetap berlaku pada tahun 2014 .

${ }^{36}$ Ibid.
} 
memakai baju kurung muslim dengan mudhawarahnya/segi tiga, rok hitam, dan siswa putera memakai koko dan dianjurkan memakai kopiah nasional. ${ }^{37}$

Jika pada kedua ketentuan di atas terdapat kategorisasi siswa berdasarkan agama, maka pada dua peraturan berikutnya tak menyebutkan sama sekali kategorisasi sehingga menimbulkan pertanyaan apakah untuk yang beragama Islam saja atau untuk seluruh siswa termasuk siswa Kristen. Untuk siswa-siswi muslim mungkin tidak menimbulkan persoalan karena jamak dipahami bahwa baju kurung disertai pakai penutup kepala berupa mudhawarah segi tiga tidak saja dipahami sebagai busana ala Minang, tapi juga pakaian muslim. Apalagi untuk hari Jumat jelas termaktub "puteri memakai baju kurung muslim dengan mudhawarahnya atau segi tiga" dan "siswa putera memakai baju koko dan dianjurkan memakai kopiah nasional."

Lalu bagaimana dengan siswa non-muslim? Apakah mereka juga harus memakai pakaian sejenis serupa dengan yang dipakai oleh temanteman mereka yang beragama Islam? Jika benar demikian, bukankah sesuai dengan instruksi Walikota Padang seperti dikutip di awal bagi siswi nonmuslim hanya dianjurkan untuk memakai baju kurung bukan busana muslimah, walau dalam kenyataannya mereka terpaksa berbusana muslimah? Inilah anomali dari apa yang belakangan disebut sebagai politik identitas ketika yang menjadi basis perjuangan adalah aspirasi kelompok. ${ }^{38}$ Jamak dipahami kalau Sumatera Barat termasuk Kota Padang adalah salah satu provinsi yang paling banyak memproduksi perda-perda yang bernuansa syariah pasca reformasi yang berakar pada filosofi hidup orang Minang, Adat Basandi Syara' Syara' Basandi Kitabullab. ${ }^{39}$ Ini berimplikasi

\footnotetext{
${ }^{37}$ Ibid.

38 Bagir, Pluralisme Kewargaan, 18-20.

${ }^{39}$ Melissa Crouch, "Religious Regulations in Indonesia: Failing Vulnerable Groups," Review of Indonesian and Malaysian Affairs, Vol. 43, No. 2 (2009): 8, Michael Buehler, The Politics of Shari' a Law: Islamist Activists and the State in Democratizing Indonesia (Cambridge: Cambridge of University Press, 2016), 174.
} 
pada terkonstruknya ruang-ruang publik menjadi ruang publik muslim seperti SMAN 6 dan SMKN 2.

Persoalan lain yang tak kalah pentingnya adalah pengaturan membaca Alquran sebelum belajar. Jika hal ini hanya ditujukan untuk siswa muslim, apakah tidak sebaiknya yang non-muslim keluar dulu atau ketika siswa muslim membaca Alquran yang Kristen juga membaca kitab suci mereka, sehingga kalau yang muslim diharuskan membawa perlengkapan salat dan Alquran setiap hari, maka pada saat bersamaan yang Kristen juga diharuskan membawa Alkitab. Bagitu dengan kultum, baik di SMAN 6 maupun di SMKN 2 adalah sepaket kegiatan yang disiapkan oleh siswa di masing-masing lokal yang terdiri dari bacaan Al quran dan saritilawah, kultum, salawat badar, bacaan asma al-husna, dan nyanyian religi. Sama seperti pertanyaan di atas, jika kegiatan ini ditujukan untuk siswa muslim, mengapa siswa Kristen mesti dilibatkan meski hanya sekedar tampil di depan bersama teman-teman muslimnya yang menjadi pelaksana kegiatan. Tak terkecuali juga dengan kegiatan pembelajaran Pendidikan Agama Islam, kalau memang mereka diizinkan untuk keluar ruangan, harus diingatkan pula pada guru piket untuk tidak menyuruh mereka kembali masuk lokal. ${ }^{40}$ Jika mereka diperbolehkan untuk mengikuti pembelajaran Pendidikan Agama Islam bagaimana dengan materinya? Apakah harus disesuaikan dengan kebutuhan untuk membangun toleransi atau untuk memperkuat identitas yang seharusnya hanya untuk siswa muslim?

Semua persoalan di atas, tampak menjadi sederhana di kalangan pihak sekolah. Menurut kepala sekolah SMAN 6 misalnya, berbagai program keislaman yang menimbulkan persoalan dalam konteks siswa non-muslim sudah didiskusikan. Ke-20 siswa Kristen yang bersekolah di sana sudah dikumpulkan dan diminta memberikan respon. Umumnya menurut kepala sekolah mereka memandang positif kebijakan-kebijakan tersebut dan tidak ada yang keberatan. Justru kata kepala sekolah mereka sangat nyaman.

40 ALL (17 tahun), siswa Kristen SMAN 6, Wawancara, 24-10-2014. 
Mereka bersedia menyesuaikan diri dengan aturan-aturan yang ada. ${ }^{41}$ Bahkan bersedia pula mengingatkan teman-teman muslimnya misalnya yang tidak melaksanakan salat Jumat. Siswa Kristen SMAN 6 memang mengakui hal tersebut. Hanya saja seperti yang dikatakan ALL, "tentu kami tidak mungkin menyampaikan keberatan tersebut pak. Lagi pula waktu pertemuan itu bapak kepala sekolah sudah bilang bahwa karena siswa non-muslim jumlahnya sedikit maka anda semua menyesuaikan saja dengan aturan-aturan sekolah. Masak kami mau bilang keberatan, kan segan pak." 42

Bagi pihak SMAN 6 juga pihak SMKN 2, "penyesuaian diri" merupakan pilahan yang disediakan untuk siswa non-muslim. Ini sama juga menurut mereka dengan siswa muslim yang masuk SMA Don Bosco yang juga harus menyesuaikan diri dengan aturan-aturan sekolah tersebut; ${ }^{43}$ tidak berbusana muslim-muslimah pada saat belajar kecuali waktu peringatan hari-hari besar Islam. juga tidak disediakan tempat khusus untuk salat misalnya di area sekolah kendati ada ruang atau tempat yang dapat digunakan untuk melaksanakan salat. ${ }^{44}$ Kendati SMA Don Bosco belum sepenuhnya multikultural karena siswa muslim tidak diperkenankan memakai busana muslim-muslimah sebagai pakaian seragam sekolah, akan tetapi kepala sekolah lupa kalau SMA Don Bosco adalah SMA swasta Katolik yang berada di bawah Keuskupan Padang. Sementara sekolah yang dipimpinnya adalah sekolah umum milik pemerintah yang berdasarkan ideologi Pancasila dan Undang-Undang 1945 kendati berada di kota Padang yang mayoritas siswanya beragama Islam. Lalu sampai di mana batas "menyesuaikan diri" yang dimaksud? Untuk busana muslim-muslimah seperti yang diakui juga oleh guru Pendidikan Agama Islam SMA 6, persis seperti yang dipakai oleh teman-

\footnotetext{
${ }^{41}$ Secara umum mereka sudah terbiasa dengan berbagai kebijakan keagamaan (keislaman) mengingat sebelum masuk SMAN 6 pada umumnya sudah bersekolah di sekolah-sekolah negeri yang menerapkan kebijakan tersebut, bahkan banyak pula yang mengakui sejak kelas 3 SD. FGD dengan 17 siswa Kristen SMA Negeri 6, 8-10-2014.

42 ALL (17 tahun), siswa Kristen SMAN 6, Wawancara, 2-11-2014.

${ }^{43} \mathrm{R}$ (47 tahun), Kepala Sekolah SMAN 6, Wawancara, 13-09-2014.

44 Andri Ashadi, Pengalaman Multikulturalisme, 21.
} 
teman mereka yang beragama Islam. Sementara untuk kegiatan kultum, meski tidak diabsensi mereka juga terlibat baik sebagai peserta atau sebagai pelaksana ketika lokal mereka ditunjuk sebagai pelaksana kegiatan tersebut. Sementara saat siswa muslim berdoa dan membaca Al quran, siswa Kristen sebagian mengaku berdoa juga dalam hati. Sebagian lagi mengaku diam-diam saja bahkan ada yang main game. Sedangkan untuk kegiatan pembelajaran Agama Islam, pada umumnya siswa Kristen turut serta dalam kegiatan tersebut.

Lalu bagaimana dengan kegiatan keagamaan mereka sendiri? Seluruh kegiatan keagamaan mereka dilaksanakan di luar sekolah. Untuk pelajaran agama mereka dapatkan dari gereja pada hari Minggu. "Sudah kita katakan bahwa pada hari Minggu juga ada yang di hari Jumat, lanjut kepala sekolah, mereka harus melakukan ibadah sesuai dengan ketentuan agama mereka. Dalam persyaratanya, apa saja nyanyi yang harus dihafalkan, ibadah yang dilakukan harus diikuti dengan baik yang dibuktikan dengan absensi serta nilai dari gereja masing-masing." ${ }^{45}$ Apakah di sekolah mereka boleh merayakan perayaan keagamaan semisal natal? Sambil berfikir kepala sekolah menjawab "Sejauh ini dan menurut informasi guru-guru senior di sini, mereka tidak pernah melakukannya. Mereka sadar pula sebagai minoritas karena minoritas hal itu tidak menonjol ke permukaan." 46 Sebenarnya menurut siswa Kristen SMA Negeri 6, kami juga ingin merayakanya di sekolah. tapi "itu mustahil” kata SM, siswa Kristen SMAN 6 karena kami di sini minoritas dan bertepatan pula dengan kalender libur nasional, lalu siapa yang mau hadir ungkap. ${ }^{47}$ Tetapi apakah karena minoritas lantas rekognisi dan representasi religiusitas mereka tidak bisa diterima? Pertanyaan yang tak tersedia jawabannya oleh pihak sekolah ini dijawab oleh Kepala Seksi pendidikan Menengah Dinas Pendidikan Kota Padang. Ini menurutnya terkait dengan cara pandang masyarakat Sumatera Barat pada umumnya yang menganut prinsip hidup ABS-SBK (Adat

\footnotetext{
${ }^{45} \mathrm{R}$ (47 tahun), Kepala sekolah SMAN 6, Wawancara, 13-09-2014 dan A (42 tahun), Guru Agama Islam SMAN 6, Wawancara, 18-09-2014.

${ }^{46} \mathrm{R}$ (47 tahun), Kepala sekolah SMAN 6, Wawancara, 13-09-2014.

${ }^{47}$ SM (17 tahun) dan ALL (17 tahun), siswa Kristen SMAN 6, Wawancara, 2-11-2014.
} 
Basandi Syara' Syara' Basandi Kitabullab). ${ }^{48}$ Kalau didatangkan guru Agama Kristen ke sekolah nanti mereka heboh pula. Juga terkait dengan anggaran; bagaimana mendatangkan guru agama untuk 1,2 atau beberapa orang siswa saja. ${ }^{49}$

\section{Seidentitas Tak Seiman}

Terkadang jauh sebelum fajar menyingsing DZ sudah terbangun dari pembaringan. Dibangunkan oleh suara bacaan ayat-ayat $\mathrm{Al}$ quran dari corong mesjid yang berjarak beberapa meter dari rumahnya. Terlebih saat Ramadhan, hampir tiap hari ia terbangun ketika "garin-penjaga mesjid" membangunkan jamaah untuk makan sahur. Sebagai penganut Kristen, DZ jelas tidak hendak menunaikan salat tahajjud, bersiap-siap menunggu datangnya waktu salat sunat fajar atau mempersiapkan segala sesuatu untuk makan sahur. Baginya ini sebagai pertanda bahwa fajar akan segera berganti pagi. DZ sudah bersiap-siap untuk berangkat ke sekolah agar tidak terlambat. Dari rumah ia sudah stand by dengan pakaian seragam sekolah; baju kurung dengan setelan rok sampai mata kaki dan memakai mudhawarah segi tiga, persis seperti pakaian siswa muslim di kota Padang. Selain keluarga dan tetangga di kiri kanan rumahnya, tak banyak yang menyangka kalau ia seorang siswa perempuan beragama Kristen yang terlahir dari ayah dan ibu penganut Kristen Protestan. Namun pada saat yang sama harus mengenakan pakaian seragam muslimah yang lazimnya dipakai oleh siswa muslim lantaran bersekolah di sekolah negeri. Ia sudah biasa memakainya, sejak SD, saat kewajiban berbusana muslim muslimah diterapkan pada semua siswa di Kota ini. Hampir separoh hari dan waktunya dihabiskan dengan mengenakan jilbab, termasuk juga kegiatankegiatan keislaman lain seperti kultum setiap Jumat pagi yang juga

\footnotetext{
${ }^{48}$ Konstruks ABS-SBK sering dipakai untuk mengidentikkan antara keminangan dengan keislaman baik sebagai identitas kultural yang melekat pada identitas orang Minang sekaligus ketika otonomi daerah digulirkan dijelmakan sebagai identitas ruang publik di Ranah Minang. Oleh sebab itu, ruang publik seperti sekolah umum milik pemerintah sekalipun asal berada dalam teritori wilayah keminangan mengalami pengidentikan dengan nilai-nilai Islam.

${ }^{49}$ S (52 tahun) dan YR (57 tahun), Dinas Pendidikan Kota Padang, Wawancara, 30-102014.
} 
dianjurkan sekolah kepada siswa Kristen. Meski tidak diabsen, ia harus datang lebih cepat karena kalau terlambat ia akan "dibariskan" bersama teman-teman lain yang terlambat. Ia tidak tahu lagi apakah itu sebuah keterpaksaan atau kebiasaan. Yang jelas menurutnya sudah biasa saja; tidak merasa aneh juga tidak merasa terpaksa. ${ }^{50}$

DZ tidak sendirian, bersamanya juga ada ITW, teman satu sekolahnya di SMKN 2 dan juga satu tempat tinggal dengannya di pinggiran Kota Padang. Sama-sama keturunan Nias, hanya saja ITW terlahir di Kota Padang, sudah generasi yang ke lima tutur Ibunya, A. Ia lebih beruntung dari DZ karena di kelas ia masih dipercaya teman-temannya yang mayoritas muslim untuk menjadi ketua kelas. bahkan sejak kelas I, Ia sering merapikan pakaian seragam sekolah yang dipakai oleh teman-teman muslimnya dan teman-temannya senang, "merekapun senang ketika dibantu merapikan mudhawarah atau jilbab mereka yang terlihat kurang rapi." Ia juga sering dijadikan contoh oleh guru-guru di sekolahnya tentang rapinya siswa non-muslim dalam mengenakan seragam sekolah sekalipun itu busana muslimah. Bahkan ITW turut mengingatkan teman-teman muslimnya untuk salat dan membantu mengambilkan absensinya. Sama dengan DZ, ia juga tidak keberatan mengenakan jilbab, sudah sejak SD ia kenakan pakaian tersebut. ${ }^{51}$

Berbeda dari DZ dan ITW, SM siswa kelas XI SMAN 6 dengan gampang saja berucap "astagfirullah" ketika kaget atau terkejut terhadap sesuatu. Terkadang ungkapan seperti itu mengalir saja termasuk saat berhadapan dengan guru-gurunya. Bertemu teman-teman muslim, ia tampak akrab, juga dengan mudah saja berujar "hai, hallo kawan, assalamu'alaikum." Suatu kali ia bercerita, ketika teman-teman muslimnya hendak melakukan salat berjamaah dan sedang berwudhu, lalu gurunya bertanya." Kok kamu belum berwudhu juga SM"? Lalu teman-temannya ketawa semua, sambil mengatakan,"Ia non muslim pak." Guru tersebut, tutur SM, sampai kaget, tak menyangka kalau ia masih Kristen; padahal

${ }^{50}$ DZ (17 tahun), siswa Kristen SMKN 2, Wawancara, 28-10-2014.

${ }^{51}$ ITW (17 tahun), siswa Kristen SMKN 2, Wawancara, 27-10-2014. 
menurut perkiraan guru yang bersangkutan ia sudah muallaf. Ketika belajar Agama Islam di kelas ia serius dan mendalami walau terkadang blank; bingung termasuk mendengarkan secara seksama bacaan ayat-ayat suci Alquran. Ia merasa merinding ketika mendengar bacaan-bacaan tersebut disebabkan auranya yang lain dari bacaan-bacaan lain. Hanya saja ketika ditanya perbandingannya dengan ketika mendengar ayat-ayat Injil dibacakan pendeta, dengan sederhana ia simpulkan, "kalau Injil dapat dimengerti sementara Alquran tidak., 52

N, ITW dan SM setidaknya merupakan potret umum siswa Kristen yang bersekolah di SMAN 6 dan SMKN 2. Di tengah ketiadaan pilihan dan untuk dapat bersekolah pada sekolah idaman, mereka harus bernegosiasi dengan keadaan dengan cara meniru untuk seperti saudarasaudara mereka yang beragama Islam. Ibaratkan bunglon atau kupu-kupu mereka memiliki kemampuan untuk mengubah warna diri menjadi seperti warna daun atau bahagian tanaman lain pada suatu tumbuhan, sehingga sulit membedakan mereka dari lingkunganya. ${ }^{53}$

Dengan demikian, meniru adalah satu-satunya cara untuk dapat dengan nyaman diterima dan menjadi bagian dari lingkungan dan struktur kemusliman ruang publik sekolah. Hanya saja "meniru" dalam pemahaman mereka bukanlah "menjadi" melainkan hanya "seperti"; serupa tapi tak sama. Di satu sisi, mereka tidak mungkin untuk menjatidirikan identitas kemusliman sebagaimana layaknya siswa muslim lantaran bukan identitas agama mereka, di samping agama sendiri adalah persoalan keyakinan yang tidak menyediakan ruang bagi keragu-raguan. Namun pada saat yang sama tentu mereka tidak mungkin pula mengekspresikan pengalaman keberagamaan mereka secara elegan di ruang publik yang sudah terkoptasi oleh nilai-nilai Islam sehingga untuk tetap bersekolah dan survive di antara teman-teman dan guru-gurunya yang mayoritas beragama Islam, jalan satu-satunya hanyalah meniru. Pada bagian lain, seorang siswa

\footnotetext{
52 SM (17 tahun), siswa Kristen SMAN 6, Wawancara, 10-11-2014.

53 Nanang Martono, Sosiologi Perubahan Sosial Perspektif Klasik, Modern, Postmodern dan Poskolonial (Jakarta: PT Rajagrafindo Persada, 2011), 57.
} 
Kristen yang berstatus sebagai siswa sekolah umum negeri di lingkungan Pemerintah Kota Padang hampir tidak mungkin keluar dari berbagai program dan kegiatan keislaman lantaran hal tersebut merupakan instruksi wali kota Padang sendiri dan di sekolah-sekolah umum negeri (termasuk SMAN 6 dan SMKN 2) dijelmakan dalam berbagai aturan dan tata tertib sekolah. Terlebih untuk seorang ITW yang dipercaya berturut-turut selama 2 tahun menjadi ketua kelas untuk teman-temannya yang mayoritas muslim.

Keterlibatan ITW yang cukup jauh dalam merapikan jilbab temanteman muslimnya, menjadi contoh untuk kerapian dalam memakai busana muslimah bahkan terlibat dalam mengambilkan absensi salat siswa muslim, tentu harus dibaca dalam konteks negosiasi di atas. Sebaliknya, di saat lain beberapa kali ITW tidak kunjung menyahut telepon peneliti lantaran sedang khusuk melaksanakan kebaktian agamanya. Kalaupun ia tampak rapi dalam memakai jilbab dan tidak jarang menjadi contoh untuk teman-temannya yang beragama Islam, tidak berarti ia senang dan bangga dengan pakaian tersebut. Baginya, busana muslimah yang ia pakai hanyalah sekedar pakaian sekolah, toh seperti argumen ibunya, "Maria saja berjilbab." Tindakan SM yang "nyaris" menyamai apa yang dibiasakan di kalangan kaum muslim seperti mengucapkan "assalamu'alaikum, astagfirullah" dan tampak seriusnya dalam mempelajari materi pendidikan Agama Islam, juga harus dibaca dalam konteks konsep peniruan di atas. Dengan cara seperti itu, sebagaimana yang diungkapnya, ia merasa lebih dihargai sebagai minoritas Kristen di tengah suadara-saudaranya yang mayoritas beragama Islam. Ketika belajar materi pendidikan Agama Islam, ia tidak pernah di sindir-sindir atau disudutkan agamanya seperti yang dialami oleh teman-temannya yang lain. Bahkan ketika jam pelajaran Agama Islam dilaksanakan menjelang istirahat atau jam terakhir, kalau tidak ingin belajar ia sudah bisa pulang lebih awal

Konsep mimikri Homi K Bhabha dapat memberikan bukti bahwa yang tertekan tidak selalu diam karena mereka memiliki kuasa untuk melawan. Konsep mimikri digunakan untuk menggambarkan proses peniruan atau peminjaman berbagai elemen kebudayaan. Ia tidaklah 
menunjukkan ketergantungan sang tertekan kepada yang menekan tetapi peniru menikmati dan bermain dengan ambivalensi yang terjadi dalam proses imitasi tersebut. Ini terjadi karena mimikri selalu mengindikasikan makna yang tidak tepat dan salah tempat; imitasi sekaligus subversi. Seperti penyamaran ia bersifat ambivalen, melanggengkan tetapi sekaligus menegasikan dominasinya. ${ }^{54}$

Gayatri Chakrovorty Spivak menggunakan istilah subaltern untuk menunjuk pihak-pihak atau kelompok yang mengalami penindasan dari kelompok lain yang lebih berkuasa. Istilah subaltern sendiri pada mulanya digunakan oleh Antonio Gramsci untuk menunjuk kelompok inferior yaitu kelompok-kelompok dalam masyarakat yang menjadi subjek hegemoni kelas-kelas yang berkuasa. Hanya saja, Spivak kemudian memperdalam dan menjelaskan siapa kelas subaltern tersebut. Lewat artikel Can the subaltern Speak, ia menyebut bahwa petani, buruh, perempuan, kelas miskin dan kelompok-kelompok lain yang tidak memiliki akses kepada kekuasaan hegemonik dapat disebut sebagai kelas subaltern. ${ }^{55}$ Mereka inilah yang acapkali mengalami tekanan berlapis atas nama ras, agama, gender, etnisitas dan sebagainya. Siswa Kristen menjalankan syariat Islam dapat diduga menjadi sasaran dari sistem sosial yang serba menekan ini. Mereka berada di daerah yang memproduk nilai budaya "dima bumi dipijak di situ langik dijunjuang" (dimana bumi dipijak di sana langit dijunjung), pada saat bersamaan sedang intensif menjalankan syariat Islam; memiliki latar belakang etnis yang berbeda dengan pada umumnya orang Minang; dan berada pada struktur sosial politik yang timpang dan tidak mendapatkan tempat untuk mengartikulasikan diri.

\section{Beriman Bukan "Beragama"}

Menanggapi perilaku siswa Kristen di atas, seorang pemuka Kristen di kota ini, WS, menarik nafas panjang. Ia tampak kikuk dan cukup lama berfikir sebelum merespon ketika penulis bertanya, "apakah perilaku siswa

\footnotetext{
${ }^{54}$ Ibid.

${ }^{5}$ Ibid., 56.
} 
Kristen di atas memiliki pijakan normatif dari Alkitab atau landasan empiris dalam tradisi kekristenan"? Walau kemudian ia menjawab, "yach ngak ada bang. Itu hanya bisa dilakukan oleh orang yang mau dan mampu untuk itu. Mungkin ya karena pertimbangan itu tadi, misalnya biaya. Kan di sekolah negeri lebih murah biaya dibanding sekolah swasta atau yayasan." "Lama berfikir" seakan memberi isyarat bahwa yang dilakukan siswa Kristen seperti yang direpresentasikan oleh NZ, ITW dan SM adalah sesuatu yang tidak lazim, aneh bahkan mungkin terbilang nekad karena samasekali tidak memiliki landasan baik dari sisi normatif ayat-ayat Injil maupun dari sisi tradisi yang tumbuh dan hidup di kalangan penganut Kristen. Ketidaklaziman tersebut mungkin setara dengan andai hal yang sama terjadi di kalangan siswa muslim yang bersekolah di sekolah-sekolah Kristen, maka kecil kemungkinan ia akan keluar dari cap "kafir", "murtad" dan sejenisnya.

Namun apakah dengan begitu mereka sudah kehilangan jati diri sebagai penganut Kristen yang taat atau setidak-setidaknya terpengaruh oleh berbagai program dan kegiatan keislaman di sekolah mereka? Hal ini mengingat sebagian mengakui sudah sejak kelas III SD terlibat dalam berbagai program dan kegiatan-kegiatan keislaman di atas. Jika ukurannya "sudah terbiasa" seperti pernyataan DZ dan "nyaris menyamai" seperti yang ditampakkan SM, dapat dikatakan mereka sudah terpengaruh kalau tidak akan dikatakan kehilangan jati diri sebagai penganut suatu agama yang baik. Ini disebabkan karena agama tidak hanya sekedar petunjuk dan pengarah perilaku, tapi dalam batas tertentu juga memberi batasan bentuk suatu perilaku jika dihubungkan dengan agama lain. ${ }^{57}$ Hanya saja bila ditelusuri lebih jauh mereka tidak hanya memiliki sikap toleran seperti yang sudah diuraikan, tapi juga penganut Kristen yang militan. Hanya militansi sikap beragama mereka tujukan ke dalam, bukan keluar. AP, ketua OSIS SMKN 2 memberikan penilaian kalau siswa Kristen SMKN 2 termasuk yang fanatik terhadap agama mereka. Kalaupun siswa Kristen hadir dalam

56 WS (48 tahun), pemuka Kristen Kota Padang, Wawancara, 25-10-2014.

57 Charles Kimball, Kala Agama Jadi Bencana, Terj. Nurhadi dan Izzuddin Washil (Bandung: Mizan, 2013), xiv-xv. 
acara kultum atau ikut belajar pendidikan Agama Islam menurutnya lebih sekedar partisipasi mereka karena bersekolah di sekolah yang mayoritas siswanya adalah muslim. Kitapun menurut AP memang mengharapkan agar mereka menunjukkan partisipasi tersebut. Mereka, lanjutnya, tidak mau ikut-ikutan menjadi pelaksana acara; hanya sekedar hadir saja. Meski kalau lebaran mereka juga sering datang ke rumah siswa yang muslim. ${ }^{58}$

Sepengetahuan Y, Guru senior PAI SMKN 2, baru satu orang siswa Kristen yang pindah ke agama Islam yang menurut dugaannya karena sering mengikuti pelajaran Pendidikan Agama Islam dan Budi Pekerti yang ia ampu. ${ }^{59}$ Sebaliknya tidak jarang justru siswa Kristen merasa tersudutkan dengan pola pengajaran Agama Islam yang selalu dikait-kaitkannya dengan agama Kristen. Alih-alih mencari simpati malah antipati seperti yang dialami SLB. Ia tak habis pikir mengapa guru tersebut selalu mengaitgaitkan materi Pendidikan Agama Islam dengan agamanya yang membuat ia tersudut dan merasa direndahkan. Ia bahkan pernah mengeluhkan hal tersebut pada orang tuanya. Orang tuanya pun marah, dan ingin menemui guru yang bersangkutan. Namun ia larang karena khawatir dengan kelangsungan sekolahnya. ${ }^{60} \mathrm{Hal}$ yang sama juga dialami ALL, siswa Kristen SMAN 6. Ia bahkan sampai menangis dan mengadukan ke guru BK ketika guru Agama Islam di sekolahnya menyatakan, bahwa yang disalib itu bukan Yesus, melainkan pengkhianat yang diserupakan dengan Isa, Yudas Iskariot. "Yach tersinggunglah saya pak, masak dikatakan yang disalib itu pengkhianat. Kayak dia saja yang paling benar pak," ungkapnya tampak kesal. ${ }^{61}$ Ia sama sekali merasa tidak terpengaruh dengan ajaran Islam yang terus menerus diinternalisasikan di sekolahnya. Baginya ini lebih sebagai jalan untuk mengenal perbedaan dan persamaan di antara agama-agama. ALL sendiri mengaku sering diajak teman-temannya untuk pindah agama ke Islam. Lalu karena keseringan ia katakan, "sekarang begini saja, aku pindah ke agamamu, nanti kamu pindah pula ke agamaku, biar kita saling

58 AP (16 tahun), Siswa Muslim SMKN 2, Wawancara, 17-09-2014.

${ }^{59}$ YG (54 tahun), guru SMKN 2, Wawancara, 17-09-2014.

${ }^{60}$ SLB (18 tahun), siswa Kristen SMKN 2, Wawancara, 27-10-2014.

${ }^{61}$ ALL (17 tahun), siswa Kristen SMAN 6, Wawancara, 24-10-2014. 
rasain." DZ yang mengaku sudah terbiasa dengan program dan kegiatan keislaman bahkan mengkritik teman-teman muslimnya yang harus diabsen dulu untuk salat, "masak diabsen, salat itu kan untuk dia."

Lalu bagaimana sesungguhnya mereka memaknai Kristen sebagai agama dan identitas laten pada diri mereka dengan identitas keislaman menifes hasil bentukan ruang publik sekolah? Bukankah seperti dikatakan Fanon, mereka telah masuk ke dalam tubuh, ke dalam cara pandang dan ke dalam lokasi lain yang mengharuskan berempati dan meletakkan dirinya dalam sudut pandang dan perspektif orang lain? Keberagamaan bagi mereka tampaknya lebih merupakan urusan dalam, iman atau kepercayaan. Kendati DZ misalnya tidak mau mengungkapkan simpul-simpul keimanannya, namun ia selalu mengingat pesan pendetanya untuk tidak terpengaruh dan jangan sampai menyangkal Tuhan kendati terlibat secara langsung atau tidak langsung dengan berbagai program dan kegiatan keislaman di sekolahnya. ${ }^{63}$ Kata iman sendiri dalam agama Kristen memang mengacu pada rasa percaya pada Allah dan percaya pada firmanNya. Percaya pada Allah mencakup arti bahwa ia benar dan dapat diandalkan, mempercayakan diri pada-Nya dan taat serta setia pada-Nya. Sementara percaya pada firman-Nya berarti percaya dan menerima apa yang sudah difirmankan-Nya, termasuk percaya pada Yesus Kristus sang juru selamat. ${ }^{64}$ Lukas 7:50; 8:40; 17:19; 18:42 menyebut karena "imanmu menyelamatkanmu." ${ }^{95}$ Mengingat agama lebih merupakan urusan iman, maka bagi DZ beribadah tidak mesti di gereja. "kita dapat beribadah di mana saja, kan Tuhan berada di mana-mana. Dan beribadah itu tidak perlu dipamerkan, dilihat orang. Kita bisa saja berdo'a dalam hati. ${ }^{66}$

Dengan pola pemahaman seperti itu, DZ tampak telah merasionalisasikan pilihannya ketika memilih untuk bersekolah di sekolah

\footnotetext{
${ }^{62}$ NZ (15 tahun), siswa Kristen SMKN 2, Wawancara, 28-10-2014.

${ }^{63} \mathrm{NZ}$ (15 tahun), siswa Kristen SMKN 2, Wawancara, 28-10-2014.

${ }^{64} \mathrm{Http}: / /$ www.alkitab.or.id/biblika/RuangIstilah4.htm (diakses 21 Maret 2015).

65 Albertus Sujoko, Militansi dan Toleransi Refleksi Teologis atas Rabmat Sakramen Babtis (Yogyakarta: Kanisius, 2012), 6.

${ }^{66}$ DZ (17 tahun), siswa Kristen SMKN 2, Wawancara, 28-10-2014.
} 
negeri di Kota Padang. Kendati harus terlibat dalam kegiatan kultum dan mengenakan busana muslimah, namun tidak dimaknainya sebagai masalah iman dan ibadah. Iman dan ibadah urusan dalam dan itulah yang ia maknai sebagai agama yang sesungguhnya, sementara keterlibatannya dengan kegiatan keislaman lebih merupakan urusan luar yang tidak ada sangkut pautnya dengan agama. Menggunakan kerangka Franz Fanon, DZ telah membelah ruang identitas antara ruang fantasi dan ruang kedirian yang menjadi miliknya. Untuk "menjadi berada", dalam konteks ruang fantasi, ia harus masuk ke dalam tubuh, ke dalam sudut pandang ke lokasi atau tempat lain; itulah ruang publik sekolah yang telah berubah menjadi ruang publik muslim. Sementara ruang yang sesungguhnya, yang tetap dipertahankan dan menjadi miliknya adalah iman yang tidak butuh penampakan simbolik. Lagi pula menurutnya, di samping tidak terdapat ketentuan agamanya dalam soal tersebut, seperti yang juga dipahami oleh temannya ITW, Maria saja berjilbab.

Dengan cara seperti ini, ia tampak senang menjalani berbagai kegiatan keislaman sekolahnya. Sehingga dengan demikian ketika ditanya apakah ia menjalaninya dengan keterpaksaan? Dengan lugas ia menjawab, tak tahu lagi apakah ini keterpaksaan atau bukan. Yang jelas menurutnya merasa sudah biasa atau terbiasa saja. Ia juga tidak merasa tersisih ketika kegiatan keagamaannya tidak mendapat ruang representasi karena menurutnya di sekolahnya mayoritas memang siswa muslim. ${ }^{67}$

Pemahaman serupa juga tampaknya yang memuluskan SM untuk memperagakan berbagai kegiatan keislaman seperti mengucapkan "assalamu'alaikum", "astagfirullah" dan "masaallab", sama seperti yang lazim dilakukan oleh teman-teman muslimnya. Suatu kali, SM yang akrab dengan para guru dan siswa muslim tersebut, bercerita, "sebenarnya siswa Kristen tidak diwajibkan untuk mengikuti kegiatan kultum pak. Tapi hanya sekedar untuk 'meramai-ramaikan.' Segan pula dengan kawan-kawan muslim.. ${ }^{\prime 68}$ Ini menunjukkan kalau ia sudah memisahkan antara wilayah

${ }^{67}$ DZ (17 tahun), siswa Kristen SMKN 2, Wawancara, 28-10-2014.

${ }^{68} \mathrm{SM}$ (17 tahun), siswa Kristen SMAN 6, Wawancara, 10-11-2014. 
agama-iman dan bukan agama karena keikutsertaannya dalam kegiatan kultum lebih dimaknai sekedar meramai-ramaikan dan merasa segan dengan kawan-kawan muslimnya kalau tidak menghadiri kegiatan tersebut. Sikap serupa juga ditunjukkan ITW yang sering dijadikan model oleh sekolah tentang rapinya seorang Kristen berjilbab bagi kebanyakan temanteman muslimahnya, termasuk turut membantu mengambilkan absensi salat teman-teman muslim di tempat salat. Cara pandang tersebut, menggunakan perspektif ST Sunardi, menempatkan agama pada sikap yang mempercayai hidup, penekanan pada hidup dan cara hidup dan yang terpenting menurutnya bahwa agama menyangkut soal perjumpaan dengan yang kudus atau Tuhan. ${ }^{69}$

\section{Penutup}

Penelitian ini menyimpulkan setidaknya tiga hal. Pertama, berbagai kebijakan keislaman yang dimplementasikan dalam proses belajar mengajar baik di SMAN 6 maupun di SMKN 2 terlihat ambivalen. Pada satu sisi secara jelas ditujukan terhadap siswa-siswi yang beragama Islam seperti kewajiban membawa $\mathrm{Al}$ quran setiap hari dan salat berjamaah. Namun di sisi lain melibatkan semua siswa termasuk siswa Kristen seperti kewajiban untuk berpakaian muslim-muslimah, kultum dan pembelajaran Pendidikan Agama Islam dan Budi Pekerti. Khusus untuk kewajiban berbusana muslim-muslimah sejak dari awal mereka sudah diingatkan untuk "menyesuaikan diri" seperti siswa-siswi muslim. Sementara kendati tidak diabsensi, dalam kegiatan kultum mereka harus terlibat karena jika terlambat akan "dibariskan" bersama siswa yang terlambat dan kalau lokal mereka menjadi pelaksana, maka mereka harus juga tampil walau hanya sekedar berdiri di depan. Dan dalam kegiatan pembelajaran Agama Islam dan Budi Pekerti, kendati dizinkan keluar, namun tidak jarang guru piket

69 Th Sumarthana, dkk, Dialog: Kritik dan Identitas Agama (Yogyakarta: Pustaka Pelajar, 1991), 86 . 
menyuruh kembali ke lokal. Alhasil mereka mau tidak mau terlibat dalam kegiatan tersebut.

Kedua, dalam kondisi minoritas dan ketiadaan pilihan, maka mereka terpaksa menyesuaikan diri dengan berbagai argumen; memakai pakaian muslim-muslimah karena "Maria saja berjilbab", sedangkan terlibat dalam kegiatan kultum dan pembelajaran pendidikan Agama Islam dan Budi Pekerti hanya sekedar "meramai-ramaikan" karena segan dengan dengan teman-teman muslim. Meskipun begitu mereka tetap tidak kehilangan jati diri sebagai siswa-siswa Kristen yang taat. Kendati tampak rapi dalam memakai busana muslim-muslimah, namun di baliknya tergantung kalung salib sebagai simbol integritas dan penyelamatan diri hanya melalui Yesus Kristus; tidak belajar agama di ruang sekolah, namun mereka tetap rajin mengunjungi gereja untuk beribadah dan mendalami pengetahuan keagamaan; di saat yang muslim berdo'a dan mengaji, mereka juga berdoa dalam hati dan untuk lebih konsentrasi tidak jarang mereka mengambar salib besar di buka catatan.

Ketiga, oleh sebab itu, riset ini merekomendasikan untuk memperjelas dan mempertegas batas-batas menyesuaikan diri dalam program keislaman sekolah yang terbuka untuk semua siswa. Jika dimaknai sebagai kegiatan seremonial-kultural, tidak mesti menggunakan terma-terma keislaman misalnya alih-alih menyebut busana muslim-muslimah, sebut saja pakaian kebaya ranah Minang. Begitu juga dengan kegiatan kultum, sebut saja misal pencerahan spiritual atau training ESQ. Manakala sudah dimaknai sebagai bahagian dari kegiatan ibadah, sudah selayaknya tidak melibatkan siswasiswi non-muslim agar tidak menimbulkan kesalahpahaman dan keresahan. 


\section{Daftar Pustaka}

Abdullah, Irwan. Konstruksi dan Reproduksi Kebudayaan. Yogyakarta: Pustaka Pelajar, 2010.

Abidin Bagir, Zainal dkk. Pluralisme Kewargaan Arab Baru Politik Keragaman di Indonesia. Yogyakarta: CRCS UGM bekerjasama dengan Mizan, 2011.

Ansar, Muhammad. Salib Dibalik jilbab: Negosiasi Indentitas Perempuan Kristen Beriilbab di Langsa Aceh. AICIS, IAIN Samarinda. 2014.

Ansar, Muhammad. Yang Bersalib Yang Berillbab: Politik Representasi dan Negosiasi Identitas Perempuan Kristen Langsa. Jakarta: Pusat Penelitian Kehidupan Keagamaan Kementerian Agama Republik Indonesia, 2013.

Ashadi, Andri dkk. Kebijakan Multikulturalisme terbadap Pelajar Islam dan Kristen; Studi Kasus SMAN 6 dan SMKN 2 Padang. Padang: Pusat Penelitian dan Penerbitan IAIN Imam Bonjol, 2014. - Pengalaman Multikulturalisme di Kalangan Pelajar Islam dan Kristen SMA Don Bosco Padang. Padang: Pusat Penelitian dan Penerbitan IAIN Imam Bonjol, 2013. , Mengalami Keberagaman, Menjadi Multikulturalis: Studi atas Pengalaman Multikulturalisme Siswa Muslim SMA Don Bosco Padang. AICIS, IAIN Samarinda, 2014.

Azra, Azyumardi. Merawat kemajemukan Merawat Indonesia. Yogyakarta: Institute Pluralisme and Multikulturalism Studies (impuls) dan Kanisius, 2007.

Budiawan (ed). Ambivalensi Post-Kolonialisme Membedah Musik sampai Agama di Indonesia. Yogyakarta: Jalasutra, 2010.

Buehler, Michael. The Politics of Shari'a Law: Islamist Activists and the State in Democratizing Indonesia. Cambridge: Cambridge of University Press, 2016.

Crouch, Melissa. "Religious Regulations in Indonesia: Failing Vulnerable Groups," Review of Indonesian and Malaysian Affairs, Vol. 43, No. 2, 2009. 
Dwipayana, Ari. "Pendidikan Umat: dari Pluralisme ke Multikulturalisme," Majalab Gema Duta Wacana, 2003.

K. Bhabha, Homi. "Introduction: narrating of the nation", Nation and Narration, Homi K. Bhabha (ed). London and New York: Routledge, 1990.

Kimball, Charles. Kala Agama Jadi Bencana. Terj. Nurhadi dan Izzuddin Washil. Bandung: Mizan, 2013.

Mandiri, Tim Fokusindo. Undang-Undang Sistem Pendidikan Nasional. Bandung: Fokusindo Mandiri, 2012.

Martono, Nanang. Sosiologi Perubahan Sosial Perspektif Klasik, Modern, Postmodern dan Poskolonial. Jakarta, PT Rajagrafindo Persada, 2011.

Moqsith Ghazali, Abd. Argumen Pluralisme Agama Membangun Toleransi Berbasis Alquran. Depok: Kata Kita, 2009.

Press, Tim Permata. Undang-Undang Sisdiknas Sistem Pendidikan Nasional \& PP No 32 Tabun 2013 tentang Perubaban PP No 19 Tabun 2005 tentang Standar Pendidikan Nasional, 2013.

Bowen, John R. Why the French Don't Like Headscarves: Islam, the State and Public Space. Princeton and Oxford: Princeton University Press, 2007.

Ropi, Ismatu. "Rohis: dari Pencarian Identitas ke Ideologisasi Agama"

Dialog Jurnal Penelitian dan Kajian Keagamaan. Vol. 72, No. 2, Nopember 2011.

Salim, Hairus HS dkk. Politik Ruang Publik sekolah Negosiasi dan Resistensi di SMUN di Yogyakarta. Yogyakarta: CRCS-UGM, 2011.

Sefriyono. Harmoni dalam Perbedaan: membangun Integrasi dari Bawah Ala Masyarakat Padang Selatan. Padang: Puslit IAIN Imam Bonjol, 2013. Sujoko, Albertus. Militansi dan Toleransi Refleksi Teologis atas Rahmat Sakramen Babtis. Yogyakarta: Kanisius, 2012.

Sumarthana, Th dkk. Dialog: Kritik dan Identitas Agama. Yogyakarta: Pustaka Pelajar, 1991.

http://hukum.kompasiana.com/2014/01/30/jilbab-dan-tiranimayoritas-631665.html 
http://junsu.blog.fisip.uns.ac.id/2013/06/20/definisi-respons-menurutpara-ahli

http:// smansa-padang.sch.id/index.php?id=berita\&kode $=65$

http://www.apakabar.ws/content/view/3429/

http://www.dikti.go.id/files/atur/PP17-2010Lengkap.pdf

http://www.elsam.or.id/downloads/1269181690_Tulisan_Monitoring_

Perda_-_surur.pdf

http://www.elsam.or.id/downloads/Tulisan_Monitoring_Perda-

surur.pdf

http://www.eocdlr.org.hk/downloads/document_indonesian.pdf

http://www.palgraveconnect.com/pc/doifinder/10.1057/97802301176

48

Buku Induk Siswa SMKN 2 Padang atas nama Nurzaman tahun 2013/2014.

Instruksi Walikota Padang nomor 451.422/Binsos-III/2005.

Peraturan Menteri Pendidikan dan Kebudayaan Nomor 69 tahun 2013

tentang Kerangka Dasar dan Struktur Kurikulum Sekolah Menengah Atas/Madrasah Aliyah.

Peraturan Menteri Pendidikan dan Kebudayaan Republik Indonesia

Nomor 70 Tahun 2013 tentang Kerangka Dasar dan Struktur

Kurikulum SMK/MAK.

Permendiknas No. 22 tahun 2006 tentang Standar Isi Satuan Pendidikan

Dasar dan Menengah.

Rekap Jumlah Siswa SMKN 2 Padang Januari 2014.

Surat Edaran Kepala Dinas Pendidikan Kota Padang nomor 1565/420.DP/TU.2/2005.

\section{Wawancara:}

1. R, (47 tahun), pihak sekolah SMAN 6, 9-10-2014.

2. A, (42 tahun), pihak sekolah SMAN 6, 15-10-2014.

3. V, (36 tahun), pihak sekolah SMAN 6, 10-10-2014.

4. Y, (52 tahun), Komite SMAN 6, 25-10-2014.

5. SA, (58 tahun), pihak sekolah SMKN 2, 15-10-2014.

6. S, (51 tahun), pihak sekolah SMKN 2, 15-10-2014. 
7. Y, (54 tahun), pihak sekolah SMKN 2, 17-09-2014.

8. S, (52 tahun), Dinas Pendidikan Kota Padang, 30-10-2014.

9. Y, (56 tahun), Dinas pendidikan Kota Padang, 30-10-2014.

10. Y, (42 tahun), Orang Tua Siswa Kristen SMAN 6.

11. A, (44 tahun), Orang Tua Siswa Kristen SMKN 2.

12. TB (40 tahun), Orang Tua Siswa Kristen SMKN 2.

13. WS, Pemuka Agama Kristen Kota Padang, 25-10-2014.

14. AP, (16 tahun), Siswa Muslim SMKN 2, 27-9-2014.

15. ITW, (17 tahun), Siswa Kristen SMKN 2, 27-10-2014.

16. LSS, (17 tahun), Siswa Kristen SMKN 2, 27-10-2014.

17. SLB, (18 tahun), Siswa Kristen SMKN 2, 27-10-2014.

18. DZ, (17 tahun), Siswa Kristen SMKN 2, 28-10-2014.

19. ALL, (17 tahun), Siswa Kristen SMAN 6, 8-9-2014.

20. SM, (17 tahun), Siswa Kristen SMAN 6, 8-9-2014.

21. KH, (15 tahun), Siswa Kristen SMAN 6, 8-9-2014.

Fokus Group Discussion: 9-10-2014

1. ALL, (17 tahun), Siswa Kristen SMAN 6.

2. SM, (17 tahun), Siswa Kristen SMAN 6.

3. KH, (15 tahun), Siswa Kristen SMAN 6.

4. WN, (16 tahun), Siswa Kristen SMAN 6.

5. IDF, (17 tahun), Siswa Kristen SMAN 6.

6. AT, (17 tahun), Siswa Kristen SMAN 6.

7. AKL, (17 tahun), Siswa Kristen SMAN 6.

8. RA, (17 tahun), Siswa Kristen SMAN 6.

9. ARH, (15 tahun), Siswa Kristen SMAN 6.

10. BS, (15 tahun), Siswa Kristen SMAN 6.

11. DHN, (16 tahun), Siswa Kristen SMAN 6.

12. MR, (14 tahun), Siswa Kristen SMAN 6.

13. GWP, (15 tahun), Siswa Kristen SMAN 6.

14. SNZ, (15 tahun), Siswa Kristen SMAN 6.

15. ICYH, (15 tahun), Siswa Kristen SMAN 6.

16. SFKK, (16 tahun), Siswa Kristen SMAN 6.

17. WLJZ, (15 tahun), Siswa Kristen SMAN 6. 